Article History:

Received: 24 July 2021; Revised: 18 August 2021; Accepted: 31 August 2021

Book Review

\title{
Book Review: Writing Your Journal Article in Twelve Weeks: A Guide to Publishing Success
}

\author{
Writing Your Journal Article in Twelve Weeks: A Guide to Publishing Success \\ Wendy Laura Belcher, 2019 (2nd ed.) \\ Chicago University Press \\ 427 pp., ISBN-13: 978-0226499918 320, \$60 (Paperback)
}

Reviewed by

Samikshya Bidari

Kathmandu University School of Education, Lalitpur, Nepal

Aimed at graduate students, fresh Ph.D. scholars, post-doctoral scholars, Belcher's book Writing your journal article in twelve weeks: A guide to academic publishing success guides the readers in a step-by-step manner to a twelve-week journey of writing and publishing a journal article. Considering the pressure of scholarly publication at the entry-level for a teaching or research position in a university, Belcher's book could be a practical guide to everyone who aspires for jobs in institutes of higher education. In this book article, I outline the layout and structure summarizing the main arguments of the book and then I provide my observations on the practical usefulness of the book for a doctoral scholar like me.

Belcher moves in a step-by-step manner providing her professional advice on planning, writing, and publishing research articles. Each week, readers learn the

* Reviewer Email: samikshya_phele21 @ kusoed.edu.np ISSN: 2091-0118 (Print) / 2091-2560 (Online) (D) https://orcid.org/0000-0002-5190-5358

(C) 2021 The Reviewer(s). Journal homepages: ${ }^{1}$ http://www.kusoed.edu.np/journal/index.php/je 2https://www.nepjol.info/index.php/JER/index

Published by Kathmandu University School of Education, Lalitpur, Nepal.

This open access article is distributed under a Creative Commons Attribution (CC BY-SA 4.0) license. 
Book Review: Writing Your Journal Article in Twelve Weeks | 107

characteristics of good academic articles and work on improving their own. Every day is meticulously planned, removing the guesswork and anxiety associated with writing. Tasks, models, and reminders are all included. The author makes sure that graduate students, recent $\mathrm{PhDs}$, postdoctoral fellows, novice researchers, and junior faculty understand the academic tricks of publishing, and, at the end of the twelve weeks, they get equipped with all the required skills that they need.

Divided into 15 chapters, Belcher begins her book by familiarizing the readers with her book in her introductory chapter. From Chapter Two to Chapter 13, she gives practical guidelines to the readers. Chapter Two i.e., Week One covers planning and recognizing writing emotions. Week Two guides us on how to back our claims with evidence. Week Three is abstract writing. Many authors advocate abstract comes in the final, which was not the case in this book. In Week Four, the author guides the readers on choosing the right journal for publication. Week Five is writing and refining the literature review and the citations cross-referring primary, secondary or tertiary scholarly texts. I wonder if one week is enough for this task if we do not have enough knowledge, experience, or exposure to the subject matter. Week six is dedicated to creating distinguishing arguments from significant claims. In this week our task is to answer the "So What?" in our research. Week seven is to analyse our evidence whether it is textual, qualitative, quantitative, or experimental evidence and gathering additional evidence. Week eight is showcasing the evidence with pictures, figures, statistics, or graphs and giving credit to the pictures if it's taken from an external source. Week Nine is bolstering the structure, common genres' forms, and rhetorical orders of structure. Week Ten leads us to revise the important sections from introduction to conclusion. Week Eleven is dedicated to micro revision, checking grammar, conciseness, and coherence. Week Twelve is all about giving the final touch to the article adopting journal submission guidelines and implementing the journal's documentation, punctuation, and spelling style; collecting journal submission information; and writing a submission cover letter.

Successful writers write, read, and make writing social; they continue despite rejection, and they follow their hobbies with vigour and dedication. The chapters are guided through every stage of producing a publishable article over twelve weeks, from determining which paper to concentrate readers' efforts on revising, submitting, and reacting to journal decisions. More specifically, the topics include designing readers' 


\section{8 | S. Bidari}

writing plan; starting their article; advancing arguments; selecting a journal; reviewing the related literature; strengthening the structure of the article; presenting evidence; opening and concluding the article; giving, getting, and using others' feedback; editing the language for consistency and grammatical errors, wrapping up the article; submitting the article; and finally, responding to the decisions of the journal.

The task calendar has been provided to reflect for each week. The readers are supplied with general guidance on how to use this writing guide effectively. These guidelines are again sub-divided into sections depending on the writer's disposition, discipline, career level, and whether the workbook will be used alone, with co-authors, or in a writing community, allowing each reader to choose their direction. This workbook is full of practical guidelines and procedural explanations that are made explicit, such as choosing which journal to submit to and how to provide feedback to other people's writing concisely. The author also includes valuable information on why journals usually reject submissions and brief descriptions of various scholarly articles.

While the rest of the book provides valuable details to new readers, the book's overall tone, as set by the frequent use of strong words, can be discouraging to those who possess limited to no experience with publishing. For example, the author discusses 28 anxieties, pitfalls, and traps that can cause even the most experienced professionals to work through an intoxicating interval when writing. While several of the obstacles listed appear easily managed and are well worth mentioning and addressing, such as "I write so slowly that I never seem to get much done," some, such as "I am too depressed to write" and "my childcare responsibilities are preventing me from writing" do not belong in the same category. By listing as such, novice researchers may perceive that academic communities are impersonal and inflexible, dissuading them from engaging in one altogether.

For individuals writing articles for peer-reviewed publications, this guide will prove to be a helpful resource in the end. This book lays the foundation for acquiring information that may spark the interest of prospective journal authors in an accessible manner. The book is well-paced, but with basic common sense that we all know, in a rush to publish, with the request for call for submissions from journals popping in our email inbox or social media posts, the time limit may no longer function as the author 
Book Review: Writing Your Journal Article in Twelve Weeks | 109 initially planned it. Nonetheless, I would strongly recommend this excellent book to must-have on the shelves of any institutional library or resource centre.

In conclusion, this book has the potential to captivate scholars from all regions of the world. Although the author is from the western world, she emphasized that most of her students were scholars from developing nations, women, the people of colour, nonAmericans, and first-generation academics during her years of teaching. This indicates that this book is designed to cater to the needs of diverse scholars, including scholars from the South Asian region. The other most crucial concept she highlighted in the text is that anyone can write for at least 15 minutes every day, no matter how hectic schedules are. This book can serve as a motivational tool for many.

\section{Reference}

Belcher, W. L. (2019). Writing your journal article in twelve weeks: A guide to academic publishing success (2nd ed.). Chicago University Press.

\section{To cite this article:}

Bidari, S. (2021). Book review: Writing your journal article in twelve weeks: A guide to publishing success. Journal of Education and Research, 11(2), 106-109. https://doi.org/10.51474/jer.v11i2.561 